\title{
CLASSIFICATION OF INVALID TRANSACTIONS IN PRESENT LAW DOCTRINE OF EUROPEAN COUNTRIES
}

\author{
Roman Tashian \\ Ph.D., Assistant Professor, Yaroslav Mudryi National Law University, Ukraine \\ e-mail: tashian.roman@gmail.com,orcid.org/0000-0002-6876-5857
}

\section{Summary}

The aim of this paper is providing the analysis of the classification of invalid transactions into void and voidable, which is recognized in many countries. This classification takes roots from the times of Ancient Rome, and was further developed in the 19th century thanks to the works of pandectists, primarily F.K. von Savigny and B. Windscheid. Today many European states are reforming their civil legislation. This fact allows us to take a fresh look at many institutions of civil law. In addition to the traditional approaches that are characteristic of the countries of the pandecto system, special attention should be paid to the "theorie moderne", which is widespread in the countries of the Romanesque legal system. In the context of the invalidity of transactions, the article analyzes the provisions of the legislation of the leading European countries - Germany, France, the Netherlands, Italy, Spain, Belgium. Based on the above, it is concluded that this classification of the invalidity of transactions has not lost its meaning and is relevant today.

Keywords: invalid transactions, void and voidable transactions, classification of invalid transactions, "theorie moderne" of invalid transactions.

DOI: https://doi.org/10.23856/4624

\section{Introduction}

The article is devoted to the analysis of the division of invalid transactions into void and voidable. Despite the fact that this is one of the most common classifications, it has not lost its relevance today. For example, Professor K. Turpin (Cambridge University) is one of the developers of the division of invalid acts into void and voidable. His critics noted that the simple dichotomy of invalidity is incapable of describing the various circumstances in which the law more or less refuses to give legal effect to contracts, marriages or other legal acts (Turpin, 1955:58).

\section{History brief}

First of all, it should be noted that this classification has its roots in Roman law.

Distinguishing between invalid transactions in Roman law, novelists identified the following types: 1) non-existent (negotium nullum ) - contracts in which the rules of form were not followed; 2) absolutely invalid (negotia irrita ) - contracts that have defects that the judge was obliged to take into account "in his position", namely contracts concluded by unauthorized persons, contracts with illegal and immoral conditions, and so on. These agreements were considered invalid from the moment of their conclusion and had no legal force; 3 ) relatively invalid or voidable contracts (negotia rescindibilia ) - contracts with defects for which the judge was not obliged to cancel them, unless required by the person concerned. These were contracts 
entered into by mistake, under the influence of fraud or under threat, as well as unprofitable contracts of minors. Only later, as the legal system in Roman law was simplified, did the novelists introduce a term for the voidable treaties - "conditionally valid", and also began to consider void non-existent transactions along with transactions with defects of subjects and content.

The contradistinction of void and voidable contacts was introduced by F.K. von Savigny. He distinguished between transactions that were invalid from the beginning due to a violation of the prohibition of the law (nichtig), and transactions that can be challenged, but before the challenge are valid despite the defects (anfechtbar).

The Commission on the development of the German Civil Code identified possible grounds for invalidity (nullity, non-existence, challengeability and relative invalidity), and noted that nullity and voidability are opposite types of invalidity. Relative invalidity was the third level of invalidity (Windscheid's point of view (Windscheid, 1840). As oppossed to, Savigny identified relative invalidity and voidability.

Concepts of void and voidable transactions as two forms of invalidity were developed on the basis of Roman sources by interpreting them first in the Middle Ages and commentators, but mainly in the XIX century by german pandect scientists, which clearly differentiated "Nichtigkeit" and "Anfechtbarkeit".

In the original version of the French Civil Code, the term "invalidity" was identical to the term "destruction" (annulabilité ) and therefore was not invalidity in the current sense. The terms "nullité, annuller, n'a aucun effet, nulle" were also not distinguished (Solórzano, 2010:133).

\section{The law of European countries}

However, the classification of transactions into void and voidable is recognized in many countries.

In the civil law of Bulgaria contested are contracts that are valid and binding until they are challenged or declared invalid by a party on the grounds provided by law. The definition of void contracts is enshrined in Art. 27 of the Act on Obligations and Agreements of Bulgaria. Invalid contracts are not valid and are not enforceable. Neither party is obligated to perform its obligations under this agreement, and no lawsuits may be claimed against them (Act on Obligations and Agreements of Bulgaria).

The division of invalid transactions into void and voidable is also known to the legislation of Spain. Articles 6.3 and 1,258 of the Civil Code of Spain provide that contracts that are contrary to mandatory provisions of the law are null and void, unless this law provides consequences, excellent and of worthlessness. Void are also contracts in which they lack their basic elements, in particular, consent, subject or reason (Article 1.261 of the Civil Code of Spain) (de Baranda, 2010).

Professor Yolanda Bergel Sainz de Baranda (Carlos III University of Madrid) notes, that cases of nullity of contracts are most extreme and serious and should protect the public interest. Nullity is ipso iure, which means that there is no need to claim to the court. Of course, when the parties there is disagreement as to the existence of such nullity or when one or both parties realized performance arising from the viod contract (in this case, everything should return to the situation prior to the agreement as a contract deemed never existing), perhaps may referred to court, but the court decision will be declarative only. Such a claim may be filed at any time, is not subject to the statute of limitations, and may be filed by anyone. Any person with a legitimate interest may invoke the invalidity, and the invalidity of a void transaction may be declared a judge ex officio. The Supreme Court (Tribunal Supremo) of Spain decided that 
even a person who is responsible for the nullity of the transaction, has the right to appropriate legal action (Tribunal Supremo de España, 2009).

The voidable contracts have legal force, but they have a certain defect. The voidability in Spanish civil law is called relative invalidity and is intended to protect the private interest, above all, the interest of the party to the contract. The voidability does not occur ipso iure, a court decision is required, and if the limitation of actions has expired (4 years), the contract is considered fully valid. An action for the invalidity of a contract may not be brought by the party which gave rise to the invalidity (Article 1,302 of the Civil Code of Spain). Spanish civil law also gives the parties to the voidable contract the opportunity to agree on its invalidity without going to court (Solórzano, 2010:133).

Dutch law also knows classification defects on voidness and voidability. Thus item 2 of Art. 3:40 The CC of the Netherlands says: "Contradiction with the imperative rule of law leads to the nullity of the transaction, and the nullity is formulated as a general rule of invalidity. Voidability is established as an exception to the general rule on the invalidity of transactions, which is contrary to the mandatory rule of law, when the violated rule protects only the interests of one of the parties to the transaction. The Italian Civil Code (Codice Civile) stipulates that a contract is void if it violates the rules of contract law or if its cause (causa) is inadmissible (Article 1418). The claim may be filed by any interested person, and may also be accepted by a judge officio (Article 1421). An action for invalidity is not subject to a limitation period, except for an action for restitution. A claim for invalidation of the voidable transaction may be filed only by the interested party (Article 1441), the limitation of actions is 5 years. It is possible to confirm the legal force of the transaction, which entails the impossibility to void it in the future (Solórzano, 2010:169-170).

Nullity in Europe does not require the invalidation of the transaction in court, although it is possible to file a lawsuit to establish its nullity, which is not subject to limitation of actions. But nullity may be set in court without this special claim, citing it as one of the foundation elements of the action. Voidability also means that the invalidity of the transaction following the unilateral, according to the current German law, extrajudicial declaration ( $\$ 143$ BGB) application strictly defined entities, with the possibility of such applications is limited to certain periods (see. $\S 121,124 \mathrm{BGB}$ ). If a unilateral declaration of invalidity of the transaction is not made in a timely manner, the transaction remains valid, acquiring final and full legal force (Karapetov, Tuzov, 2016:32).

\section{4. "Theorie modern"}

There should be separately noted so-called modern theory ("Theorie modern"). This theory developed in countries with a Romanesque system of civil law, primarily France, Belgium, and partly in Switzerland, and did not become widespread outside these countries.

The essence of this theory was two main points. First, the invalidity of the transaction was considered as a sanction, which was established in the absence or non-compliance with the necessary conditions for the validity of the transaction. Accordingly, nullity and voidability are the higher and lower levels of such a sanction.

Of course, in classical theory, the invalidity of the transaction is understood as a response of the legislator to certain violations, but the sanctioning, punitive nature of such consequences is not in the first place. For supporters of theorie moderne in the understanding of invalidity is the punishment itself, the desire of the legislator to bring a certain phenomenon outside the legal sphere. The intensity of the sanction (nullity or voidability) depends on the severity of the 
violation. However, in any case, it means the invalidity of the transaction. From this follows a very important conclusion: the right to invalidate transactions should be given to each person (and this is both voidable and void transactions).

Secondly, according to the proponents of this theory, there are borderline types of invalidity, which tend to be either void or disputable, but in fact they are not (Goutte, 1929:362). In general, the Civil Code of France traces the division into void and voidable (for example, Article 1117) provides for the possibility of establishing the division of invalid transactions into void and voidable.

At the same time, the analysis of further provisions allows us to conclude that this idea was not fully supported by the legislator. As an example, we can cite the provisions of the Civil Code of France, which establish the invalidity of transactions without reference to nullity or voidability. For instance, according to Art. 1339, the donor cannot eliminate defects in the form of the donation agreement by any confirmatory act; it is necessary that the donation agreement be re-concluded in the prescribed form. Thus, this construction is similar to the nullity of the contract of gift. At the same time, in accordance with Art. 1340, the heirs or successors of the donor may confirm or approve such a contract, which entails their refusal to void this contract due to a defect in form. This tends to voidability the contract.

Marriage to a mad person is void, at the same time this invalidity can be declared by a judge at the request of the prosecutor.

As a result, it should be noted that the main reason for the predominance of classical theory over theorie moderne is that the former is more in line with modern needs. The various theoretical cases of invalidity, which according to "theorie moderne" consist in different variants of invalidity, are ultimately reduced to nullity or voidability. Because of the clarity of the signs, these types of invalidity are practical and understandable (Abt, 2002:4). The weakest point of theorie modern is that, together with the denial of nullity and voidability, it offers nothing as an alternative.

At the same time, it was impossible not to mention theorie moderne, and not only for reasons of curiosity in the study of this issue. After all, it is well known that in law there are also warehouses of invalid transactions, which can not be attributed with certainty to void or voidable. The most famous case - Art. 228 of the Civil Code of Ukraine "Legal consequences of a transaction that violates public order, committed for a purpose contrary to the interests of the state and society" and the existing Article. 208 of the Economical Code of Ukraine "Consequences of invalidation of an economic obligation".

Accordingly, the question of the division of invalid transactions into void and voidable and, in particular, the grounds and essence of such a division remains relevant.

\section{Conclusions}

Thus, classical theory understands nullity and voidability as two types of invalidity. Nullity means the most severe legal consequences, and voidability occupies an intermediate place between the absolute validity and the nullity of the transaction. In French civil law invalidity means the existence of certain sanctions in the presence of circumstances provided by substantive law. In contrast to classical theory, there are many more degrees of invalidity (there are up to sixteen), and insignificance and disputability are respectively the highest and lowest links of invalidity. Intermediate types of invalidity can also tend to approach nullity or voidability. The «theorie moderne » itself does not mean a complete rejection of the division of invalid transactions into void and voidable, and the types of invalidity in one way or another are reduced to a classical dichotomy. 


\section{References}

Abt Daniel. Die Ungültigkeitsklage im schweizerischen Erbrecht: unter besonderer Berücksichtigung von Zuwendungen an Vertrauenspersonen / Daniel Abt. - Basel; Genf; München: Helbing und Lichtenhahn, 2002 (Basler Studien zur Rechtswissenschaft: Reihe A, Privatrecht; Bd. 61) Zugl.: Basel, Univ., Diss., 2001. - s. 4.

Goutte René. (1929) Système des nullités en droit suisse, in: ZSR, [in French] S. 362 ff.

Act on Obligations and Agreements of Bulgaria. Available in: http://www.bulgaria-law-of-obligations.bg/law.html

Karapetov A.G., Tuzov D.O. (2016) Sdelki, sovershennye v protivorechii s imperativnymi normami zakona, $v$ kontekste novoj redakcii st. $168 \mathrm{GK}$ RF [Transactions made in contradiction with peremptory norms of the law, in the context of the new edition of Art. 168 of the Civil Code of the Russian Federation] // Vestnik grazhdanskogo prava, № 5 [in Russian] s. 32.

Solórzano Julio Peláez. (2010). - Die Entwicklung der Nichtigkeit und der Anfechtbarkeit von Rechtsgeschäften in Deutschland und Frankreich. Mit Ausblicken auf Italien, Spanien und Guatemala. Inaugural-Dissertation zur Erlangung der Doktorwürde einer Hohen Rechtswissenschaftlichen Fakultät der Universität zu Köln. - [in German] s. 133.

Tribunal Supremo de España (March 3, 2009 and December 21).

Turpin Colin Conyngham. (1955) Void and voidable acts. 72. SALJ. [in English] P. 58 - 69.

Windscheid Bernhard. (1840). Zur Lehre des Code Napoleon von der Ungültigkeit der Rechtsgeschäfte. [in German]

Yolanda Bergel Sainz de Baranda. (2010). Inefficacy of contracts: different categories. http://www.eumed.net/libros-gratis/2015/1458/inefficacy-contracts.htm 